\title{
Phytochemical Constituents and Antioxidant Potential of Crude Extracts from Lippia Javanica (Burm.f.) Spreng Leaves
}

\author{
Foluso Oluwagbemiga Osunsanmi ${ }^{1, *}$, Godfrey Elijah Zharare ${ }^{1}$, Andy Rowland Opoku
}

\section{Foluso Oluwagbemiga Osunsanmi ${ }^{1, *}$, Godfrey Elijah Zharare ${ }^{1}$, Andy Rowland Opoku}

'Department of Agricultural Science, University of Zululand, SOUTH AFRICA. ${ }^{2}$ Department of Biochemistry and Microbiology Science, University of Zululand, SOUTH AFRICA.

\section{Correspondence}

Foluso Oluwagbemiga Osunsanmi

Department of Agricultural Science, University of Zululand, SOUTH AFRICA.

Phone no: +27-791565341

E-mail: alafin21@yahoo.com

History

- Submission Date: 18-03-2019;

- Review completed: 20-04-2019;

- Accepted Date: 25-04-2019.

DOI : 10.5530/pj.2019.11.128

Article Available online http://www.phcogj.com/v11/i4

Copyright

(C) 2019 Phcogj.Com. This is an openaccess article distributed under the terms of the Creative Commons Attribution 4.0 International license.

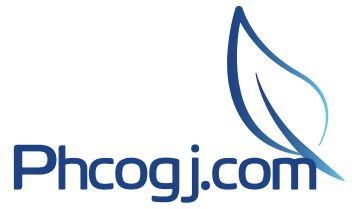

\begin{abstract}
Background: Oxidative stress is implicated in most life threaten diseases. Objectives: This study evaluated the phytochemical constituents and antioxidant activity of Lippia Javanica's crude extracts. Methods: Phytochemical screening was carried out on pulverized Lippia Javanica leaves using standard protocols. Crude extracts were prepared using various solvents (hexane, acetone, ethylacetate, methanol, dichloromethane respectively), and percentage yields calculated. The antioxidant activities of crude extracts were monitored with DPPH, ABTS and nitric oxide (NO) radicals using spectra techniques. Results: The phytochemical presents in Lippia Javanica were tannin, flavonoids, terpenoids, alkaloids and phenols. Percentage yield increased in order; Acetone > Methanol, > Dichloromethane $>$ Ethyl-acetate $>$ Hexane. All the crude extracts showed differ degrees of antioxidant potential as evidence by significantly $(P<0.05)$ scavenging DPPH, ABTS and NO radicals, Acetone crude extract showed the lowest $\mathrm{IC}_{50}\left(2.22 \times 10^{-3}\right.$ and $\left.2.42 \times 10^{-3} \mathrm{mg} / \mathrm{ml}\right)$ toward $\mathrm{DPPH}$ and ABTS radical respectively in comparison to other crude extracts, and the positive controls (Ascorbic acid and Butylated hydroxyl anisole), Hexane crude extract showed the lowest $I C_{50}\left(3.95 \times 10^{-1} \mathrm{mg} / \mathrm{ml}\right)$ toward NO radical compared with other treatments. Conclusion: Therefore, this study proves that Lippia Javanica crude extracts are good source of natural antioxidants in alleviating oxidative stress diseases. Isolation of bioactive compounds from crude extracts are desirable for future studies.
\end{abstract}

Key words: ABTS, Antioxidants, DPPH, Lippia Javanica, Phytochemicals

\section{INTRODUCTION}

Oxidative stress is considered as the aetiology of life threaten diseases including cardiovascular diseases, diabetic, renal diseases, cancer, inflammatory diseases and neurodegenerative diseases. ${ }^{1}$ These diseases are reported as the leading cause of mortality and morbidity worldwide. ${ }^{2}$ Oxidative stress is characterized by imbalance between the reactive oxygen species (ROS) and antioxidants. During oxidative stress, cytochrome P450 facilitates the production of more ROS (hydrogen peroxide, hydroxyl radical and superoxide anion radical) than non-enzymatic antioxidant (flavonoids, ascorbic acid, carotenoids, $\boldsymbol{\alpha}$-tocopherol and glutathione) and enzymatic antioxidant (catalase, glutathione perioxidase and superioxide dismustase). ${ }^{2}$ Reactive oxygen species also known to play beneficial roles in human physiology; protection of cellular system against chemical and physical insults, and in regulation of cells signalling. ${ }^{3}$ The imbalance between ROS and antioxidants results into degeneration of proteins, nucleic acids and amino acids, thus encourage cellular damages which aggravate health challenges. ${ }^{4}$

In order to mitigate this health challenges, synthetic antioxidants like butylated hydroxyanisole (BHA) and butylated hydroxytoluene (BHT) are currently used to prevents oxidative stress related diseases. However, these synthetic antioxidants are associated with side effects, including carcinogenic and liver dysfunctions. ${ }^{2}$ For this reason, the search for alternative antioxidant agents from plant origin became necessary coupled with their availability, inexpensive and minimal or no side effects. ${ }^{5}$ Plants have been the major source of tradition medicines in the world for decades. The biological activities of plants are linked to their phytochemical constituents such as phenols, flavonoids, terpenoids, alkaloids, saponins and terpenes. ${ }^{6}$ The antioxidant potentials of various plants species have also been reported in the literatures. $^{2,7}$

Lippia javanica (Burm.f.) Spreng belongs to the family of Verbenaceae. It is a perennial shrub of $4.5 \mathrm{~m}$ tall, the leaves produce lemon-fragrances when crushed. The stems are brownish with small stiff tubercles and branches possess inflorescence in all its axis. ${ }^{8}$ The plant is found growing naturally in eastern, central and southern Africa. In subSaharan, the plant is endemic to Ethiopia, Kenya, Malawi, Mozambique, Zambia, Tanzania, Uganda, Zanzibar, Zimbabwe, Swaziland and South Africa. ${ }^{9}$ Lippia javanica is commonly used as herbal tea, and other ethno medicinal applications such as asthma, diarrhoea, cold, malaria, fever, wounds, mosquito repellents, chest pain, diabetic, skin infection and heart diseases. ${ }^{910}$ However, literatures on antioxidant potential of different crude extracts from Lippia javanica's leaves is still scanty. Therefore, this study focused on investigating the phytochemical constituents and antioxidant activities of crude extracts from Lippia javanica's leaves.

Cite this article: Osunsanmi FO, Zharare GE, Opoku AR. Phytochemical Constituents and Antioxidant Potential of Crude Extracts from Lippia Javanica (Burm.f.) Spreng Leaves. Pharmacog J. 2019;11(4):803-7. 


\section{MATERIALS AND METHODS}

\section{Chemicals}

The chemicals for this study were of analytical grades, and bought from Sigma Aldrich Company Limited (Steinheim, Germany).

\section{Plant identification}

Lippia Javanica were collected at Hagaza $\left(27.467274^{\circ}\right.$ S, $\left.32.577555^{\circ} \mathrm{E}\right)$ in KwaZulu-Natal, South Africa. The plant sample was authenticated by Dr. N.T Ntuli of Department of Botany, University of Zululand. The plant specimen number FH05 was deposited at the University's herbarium,

\section{Phytochemicals constituent identification}

Pulverized Lippia Javanica's leaves was screened for the presence of tannins, saponins flavonoids, terpenoids, alkaloids, steroids and phenols following the method described by Sofowara, ${ }^{11}$ and Trease and Evans. ${ }^{12}$

\section{Preparation of various crude extracts from Lippia Javanica's}

Lippia Javanica's leaves were air dried in fume cupboard (Vivid air, VA 6003), and pulverized into fine powder with an electrical grinder (Retsch, ZM 200). Pulverized samples (50 g) were macerated with various organic solvents $(1: 5 \mathrm{w} / \mathrm{v})$ including hexane, acetone, ethylacetate, methanol, dichloromethane respectively, using mechanical shaker $\left(150 \mathrm{rpm} ; 25^{\circ} \mathrm{C}\right)$ for $72 \mathrm{~h}$. The various crude extracts were filtered with Whatman filter paper 1 , and concentrated using Buchi rotary evaporator $\left(45 \mathrm{rpm} ; 40^{\circ} \mathrm{C}\right.$; Model R- 200). The percentage (\%) yield for each crude extract was calculated using the following formula.: $\%$ yield $=\left(\mathrm{W}_{2} \times 100\right) / \mathrm{W}_{1} \cdot \mathrm{W}_{2}$ denoted weight of sample after solvent removal whereas, $\mathrm{W}_{\mathrm{I}}$ denoted weight of original sample

\section{Antioxidant assay}

\section{1,-diphenyl-2-picryl hydrazyl (DPPH) scavenging activity}

The antioxidant potential of the Lippia Javanica's crude extracts were investigated on the basis of scavenging activity of 11 , -diphenyl-2picryl hydrazyl (DPPH), as described by Huda-Faujan et al. ${ }^{13}$ with slight modification. DPPH solution $(1 \mathrm{ml} ; 0.1 \mathrm{mM})$ was mixed with $1 \mathrm{ml}$ of crude extracts of various concentrations $(0.002,0.004,0.008$, 0.0012 and $0.0020 \mathrm{mg} / \mathrm{ml}$ ). Tween 20 served as the negative control, whereas Ascorbic acid and Butylated hydroxyl anisole (BHA) was used as the positive controls. All the mixture was incubated for 60 minutes at room temperature, and absorbance was read at $517 \mathrm{~nm}$ using spectrophotometer. The percentage (\%) inhibition was calculated as follow; Inhibition $(\%)=\left(A_{1}-A_{2}\right) / A_{1} \times 100 . A_{1}$ denotes absorbance of control and $\mathrm{A}_{2}$ denotes absorbance of samples.

\section{2,21- Azino-bis (3-ethylbenzthiazoline-6- sulfonic acid (ABTS) scavenging activity}

The ABTS scavenging activity of the crude extracts were determined following the method of Otang et al. ${ }^{14}$. ABTS solution $(0.003 \mathrm{~g} / \mathrm{ml})$ was mixed in the ratio $1: 1(\mathrm{v} / \mathrm{v})$ with various concentrations $(0.002$. 0.004. $0.008,0.012,0.020 \mathrm{mg} / \mathrm{ml})$ of the crude extracts. The mixture was left to stand for $14 \mathrm{~min}$ at room temperature, and the absorbance was read at $734 \mathrm{~nm}$ using spectrophotometer. Ascorbic acid and BHA served as the positive controls whereas tween 20, the negative control. The percentage (\%) inhibition was calculated as follow; Inhibition (\%) $=\left(\mathrm{A}_{1}-\mathrm{A}_{2}\right) / \mathrm{A}_{1} \times 100 . \mathrm{A}_{1}$ denotes absorbance of control and $\mathrm{A}_{2}$ denotes absorbance of samples

\section{Nitric oxide scavenging activity}

Nitric oxide scavenging potential of crude extract was determined using Griess Illosvoy reaction as described by Govindaraian et al. ${ }^{15}$ with slight modification. Various concentrations (0'1. 0.2. 0.4. 0.6 and $1 \mathrm{mg} / \mathrm{ml})$ of crude extracts $(20 \mu \mathrm{l})$ were pipetted into respectively cell into a 96 wells plate, with each cells consisting of sodium nitroprusside phosphate-buffered saline $(30 \mu \mathrm{l})$. The 96 wells plate was then incubated at $25^{\circ} \mathrm{C}$ for 150 minutes. Afterward, sulfanilic acid reagent $(0.1$ $\mu l ; 0.33 \%$ in $20 \%$ glacial acetic acid) was pipetted into the cells and incubated for 5 minutes until diazotization reaction was completed. Naphthylethylenediamine dihydrochloride $(0.2 \mu \mathrm{l}, 0.1 \%)$ was added, and the plate was further incubated for 30 minutes at $25^{\circ} \mathrm{C}$. The absorbance was read at $540 \mathrm{~nm}$ using spectrophotometer (Biotek ELx 808 UI plate reader). Tween 20 served as the negative control, whereas butylated acid and ascorbic acid, the positive control. The percentage NO scavenging potential of crude extract was calculated as follows; $\mathrm{NO}$ scavenging activity $=\left[\left(A_{1}-A_{2}\right) / A_{1}\right] \times 100 . A_{1}$ denotes control whereas $\mathrm{A}_{2}$ indicates crude extracts treatment.

\section{Data analysis}

The experiments were carried out in triplicate, and data expressed as mean \pm standard-deviation. One-way analysis of variance (ANOVA) and Post-hoc Tukey test was used to analysed the data using the graph pad prism (version 5.03. The $\mathrm{IC}_{50}$ values were calculated by interpolating the plotted regression graph at $50 \%$.

\section{RESULTS}

\section{Phytochemical constituents of pulverized Lippia Javanica's leaves}

The results showed that tannin, flavonoids, terpenoids, alkaloids and phenols were present in Lippia Javanica's , whereas Saponin and steroids were absent (Table 1).

\section{Percentage yields of various crude extracts from Lippia Javanica's}

Percentage yield for the crudes extracts vary with type of solvents treatment (Table 2). The percentage yields of crude extracts increased in order; Acetone $>$ Methanol $>$ Dichloromethane $>$ Ethyl-acetate $>$

Table 1: The Phytochemical constituents of pulverized Lippia Javanica's leaves.

\begin{tabular}{cc}
\hline Phytochemicals & Lippia Javanica's \\
\hline Tannins & + \\
Saponins & - \\
Flavonoids & + \\
Terpenoids & + \\
Alkaloids & + \\
Steroids & - \\
Phenols & + \\
\hline
\end{tabular}

+present; - absent

Table 2: Percentage yield of Lippia Javanica's crude extracts using different solvents treatment. Data expressed as mean \pm SD. Values with different alphabets $(a, b, c)$ were significance $(p<0.05)$.

\begin{tabular}{cc}
\hline Solvent extraction & Percentage (\%) Yield \\
\hline Dichloromethane & $2.6 \pm 0.09^{\mathrm{a}}$ \\
Acetone & $4.9 \pm 0.17^{\mathrm{b}}$ \\
Methanol & $3.4 \pm 0.09^{\mathrm{c}}$ \\
Hexane & $0.9 \pm 0.06^{\mathrm{d}}$ \\
Ethyl-acetate & $2.3 \pm 0.08^{\mathrm{a}}$ \\
\hline
\end{tabular}


Hexane. Acetone crude extract showed highest significant $(P<0.05)$ percentage yield in comparison with other solvents treatment.

\section{DPPH scavenging activity of crude extract}

The crude extract significantly $(\mathrm{P}<0.05)$ increased the $\mathrm{DPPH}$ scavenging activity in dose dependent manner (Figure 1). The highest activity for all the crude extracts was observed at $0.020 \mathrm{mg} / \mathrm{ml}$. Acetone crude extract at lowest concentration $(0.02 \mathrm{mg} / \mathrm{ml})$ showed better significant $(P<0.05)$ scavenging activity than other treated crude extracts, and the positive controls (Ascorbic acid and Butylated hydroxyl anisole (BHA). Acetone and methanol crude extracts showed optimal scavenging concentration at $0.08 \mathrm{mg} / \mathrm{ml}$, further concentrations increase showed in-significant $(\mathrm{P}>0.05)$ scavenging effects. Acetone extract also showed better significant $(\mathrm{P}<0.05) \mathrm{IC}_{50}$ values $\left(2.22 \times 10^{-3}\right)$ than other treated crude extracts (Dichloromethane, Hexane and ethyl acetate), and the positive controls (Ascorbic acid and BHA) Table 3.

\section{ABTS scavenging activity}

All the crude extracts significantly $(\mathrm{P}<0.05)$ increased ABTS scavenging activity in dose dependent fashion (Figure 2). The highest percentage inhibition of the crude extracts was observed at $0.020 \mathrm{mg} / \mathrm{ml}$. Acetone crude extract showed better significant $(\mathrm{P}<0.05)$ scavenging activity at concentration range $(0.002$ to $0.008 \mathrm{mg} / \mathrm{ml})$ than other crude extracts, and ascorbic acid. Interestingly, acetone crude extract compared favourably with BHA, in all the treated concentrations. In addition to this, Acetone crude extract also showed significant better IC ${ }_{50}$ Values $\left(2.42 \times 10^{-3}\right)$ than other crude extracts and Ascorbic acids (Table 3).

\section{Nitric acid (NO) scavenging activity}

Dichloromethane crude extract showed irregular increased in NO scavenging activity. Whereas, the other crude extracts showed significant $(\mathrm{P}<0.05)$ dose dependent NO scavenging ability (Figure 3$)$. The highest

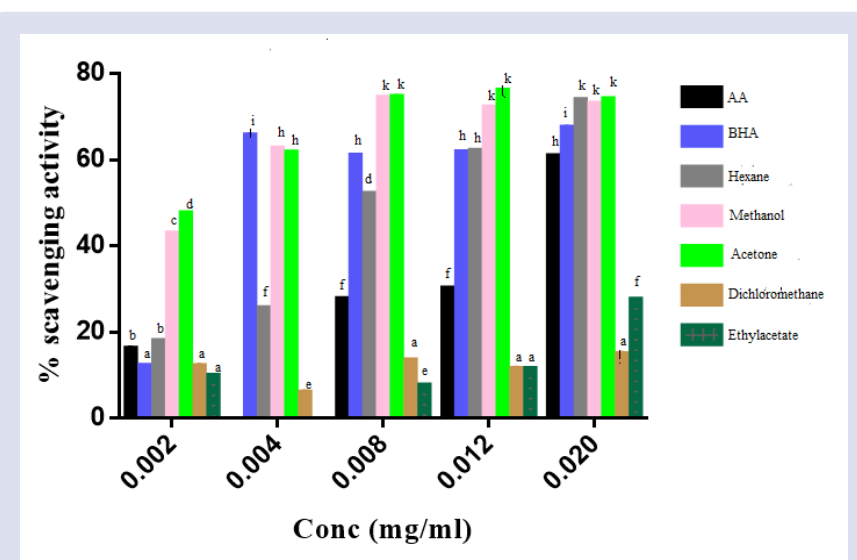

Figure 1: Percentage (\%) scavenging activity of various crude extracts from Lippia Javanica's against DPPH. Data expressed as mean \pm SD. Values with different alphabets $(a, b, c, d \ldots k)$ were significance $(p<0.05)$.

Table 3: The IC ${ }_{50}$ values of various crude extracts with ABTS, DPPH and NO assay. Values with different alphabets $(a, b, c, d)$ were significant ( $p$ $<0.05)$.

\begin{tabular}{cccc}
\hline Crude extract & ABTS $(\mathrm{mg} / \mathrm{mL})$ & DPPH $(\mathrm{mg} / \mathrm{mL})$ & $\mathrm{NO}(\mathrm{mg} / \mathrm{mL})$ \\
\hline Dichloromethane & $18.8 \times 10^{-3(\mathrm{~d})}$ & $\mathrm{ND}$ & $\mathrm{ND}$ \\
Acetone & $2.42 \times 10^{-3(\mathrm{a})}$ & $2.22 \times 10^{-3(\mathrm{a})}$ & $\mathrm{ND}$ \\
Methanol & $3.67 \times 10^{-3(\mathrm{~b})}$ & $2.67 \times 10^{-3(\mathrm{a})}$ & $\mathrm{ND}$ \\
Hexane & $12.3 \times 10^{-3(\mathrm{c})}$ & $7.67 \times 10^{-3(\mathrm{c})}$ & $3.95 \times 10^{-1(\mathrm{a})}$ \\
Ethyl-acetate & $\mathrm{ND}$ & $\mathrm{ND}$ & $\mathrm{ND}$ \\
BHA & $2.5 \times 10^{-3(\mathrm{a})}$ & $3.42 \times 10^{-3(\mathrm{~d})}$ & $\mathrm{ND}$ \\
Ascorbic acid & $\mathrm{ND}$ & $17.2 \times 10^{-3 \epsilon}$ & $\mathrm{ND}$ \\
\hline
\end{tabular}

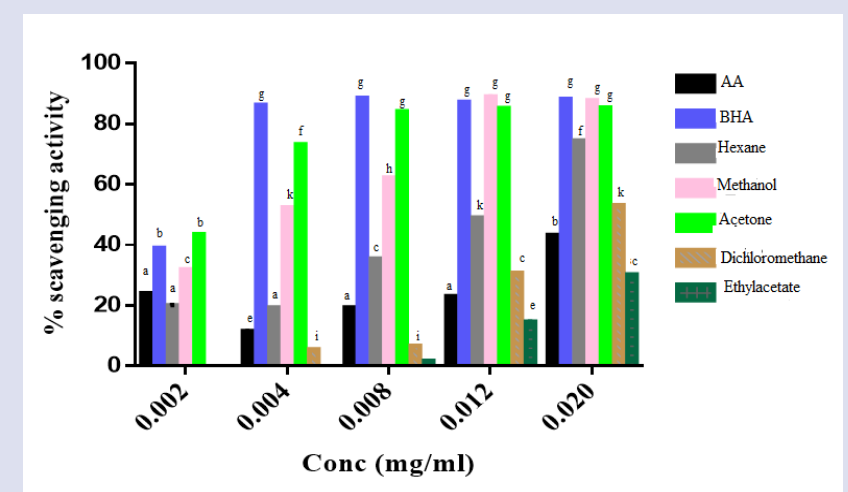

Figure 2: Percentage (\%) scavenging activity of various crude extracts from Lippia Javanica's against ABTS. Data expressed as mean \pm SD. Values with different alphabets $(a, b, c, \ldots g)$ were significance $(p<0.05)$.

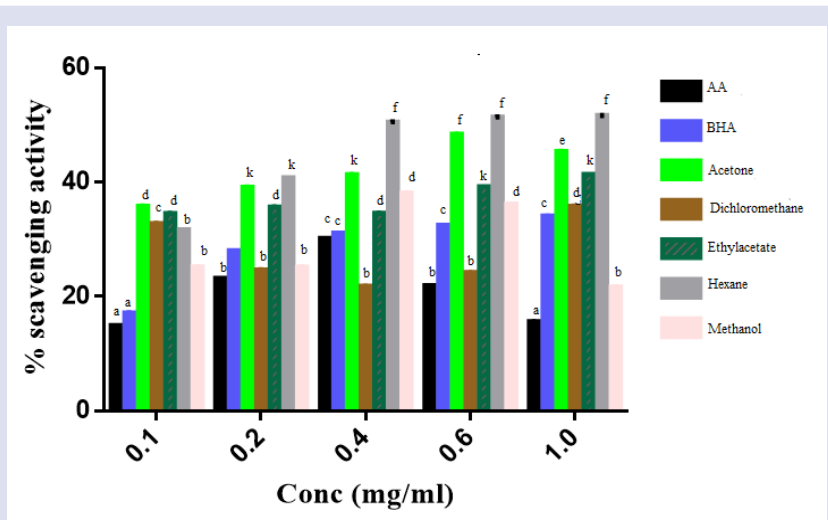

Figure 3: Percentage (\%) scavenging activity of various crude extracts from Lippia Javanica's against Nitric oxides (NO). Data expressed as mean \pm SD. Values with different alphabets $(a, b, c, d \ldots . . k)$ were significance $(p<0.05)$.

activity of the crude extracts was observed at $1.0 \mathrm{mg} / \mathrm{ml}$. The optimal scavenging concentration for hexane, acetone, ethyl acetate, methanol crude extracts was 0.4 . $0.6,0.6$ and $0.6 \mathrm{mg} / \mathrm{ml}$ respectively. However, hexane crude extract showed significant highest scavenging activity at $0.4 \mathrm{mg} / \mathrm{ml}$. Interesting, all the crude extracts exhibited significant ( $\mathrm{P}$ $<0.05$ ) better scavenging activity than the positive controls (Ascorbic acid and BHA) at lowest concentration $(0.1 \mathrm{mg} / \mathrm{ml})$. Hexane crude extract showed the lowest $\mathrm{IC}_{50}$ value $\left(3.95 \times 10^{-1} \mathrm{mg} / \mathrm{ml}\right)$ in comparison with other crude extracts and positive controls (Table 1 ).

\section{DISCUSSIONS}

Plants are indispensable source of natural products for treatment of diseases. ${ }^{16}$ Medicinal properties of plants depend on their phytochemical constituents such as steroids, saponin, alkaloids, terpenoids, phenol, proanthocyanidins and tannin. ${ }^{6}$ In this study, Lippia Javanica was confirmed to consist of tannin, flavonoids, terpenoids, alkaloids and phenols. This finding corroborated with previous reports on phytochemical screening of Lippia Javanica. ${ }^{17,18}$ All the identified phytochemicals in this study possessed antioxidant properties, thus the plant could be a good antioxidants agent in mitigating against oxidative stress related diseases. ${ }^{19}$ Phenols found in plants play crucial role as antioxidant in exhibiting therapeutic properties such as antiinflammatory, antibiotic, anti-allergic and anticancer activities. ${ }^{18}$ Flavonoid tremendous activities include; anti-viral, anti-inflammatory, anti-bacterial, and anti-oxidant. ${ }^{6}$ Alkaloids, Terpenes and Tannin have also been reported to possessed anticancer, antioxidant, anti-pyretic, 
anti-inflammatory, antidiabetic, anti-platelet aggregation and sedative activities. $^{19}$

The components and quantities of phytochemicals in crude extracts are associated with the type of solvents used for extraction. Chemical nature of phytochemicals varies; hence the phytochemicals display different solubility in a given solvent. ${ }^{20}$ The solvents used in this study are selected based on their different polarity potential. Acetone crude extract showed the highest percentage yields whereas hexane crude, the lowest yield being the least polar solvent. This finding was in accordance with the report of Gupta, ${ }^{21}$ on Datura metel plant leaves. Acetone crude extract highest percentage yield could be linked to acetone polar aprotic characteristics, in which both polar and non-polar compounds are dissolved. ${ }^{20}$ Furthermore, the highest percentage yield of acetone extract could imply that acetone is the most effective solvent extractant needed to maximize therapeutic potentials of Lippia Javanica.

Reactive oxygen species (ROS) produced during body's metabolism are implicated in many debilitating diseases including; diabetics, cancer, dementia, multiple sclerosis, cystic fibrosis stroke and heart attack. ${ }^{6}$ Antioxidant molecules possessed the capacity to neutralize the effects of those free radicals. Most antioxidants interrupt free radical chain reaction due to their redox properties, thus terminate ROS activities. ${ }^{6}$ Bio functionalities such as; suppression and prevention of oxidative stress related diseases of natural antioxidants from medicinal plants have been reported. ${ }^{22}$ This present study reported the DPPH, ABTS and NO scavenging activities of various crude extract from Lippia Javanica.

DPPH is a stable free radical with red colour (absorbance read at $517 \mathrm{~nm}$ ), delocalization of spare electrons retained DPPH stability. Scavenging agents react with DPPH solution leading to yellowish colouration, due to loss of free electrons ${ }^{23}$ In this study, all the crude extracts showed scavenging potential as evidence by increased in DPPH scavenging ability. Crude extracts from medicinal plants have previously been reported to possessed scavenging ability using DPPH assay. ${ }^{19}$ This scavenging potential could be linked to the crude extracts' phytochemicals compositions. Phenolic compounds easily lose hydrogen electron to quench ROS activities, because of its hydroxyl chemical structure. Flavonoids possessed the tenacity to compete with oxygen and derivatives by donating electrons to the free radicals..$^{13}$ The highest scavenging ability of acetone crude extract in comparison with other crude extracts, ascorbic acid and BHA in this study indicated that acetone is the most adequate solvent require to prepared crude extract with high scavenging potential. In addition, the activities of acetone crude extract could be linked to the quantity of phytochemical constituents such as phenolic compounds. Previously, acetone crude extracts from medicinal plants have been reported to possessed high level of phenolic compounds in comparison with other solvents crude extracts. ${ }^{19}$ High level of phenolic compounds have also been demonstrated to possess positive correlation with free radical scavenging ability. ${ }^{24}$

ABTS is a blue green radical reagent used to monitored scavenging ability of antioxidant agent such as thiol, flavonoids and phenol. ABTS lose its blue green colouration to become colourless during scavenging activity. ${ }^{25}$ This study revealed the antioxidant potential of all the crude extracts as evidence in scavenging ABTS radicals. This finding was in accordance with previous study in which crude extracts from medicinal plants possessed scavenging ability toward ABTS radicals. ${ }^{19}$ Crude extracts from Lippia Javanica's have previously been reported to scavenged ABTS radials. ${ }^{8}$ The ABTS scavenging activity of crude extracts in this study showed similar trend as shown in DPPH radical scavenging. This finding was contrary to report of Wange et al. ${ }^{26}$ which stipulated that compound which possessed ABTS radical scavenging ability might lack DPPH radical scavenging activity. Whereas, the report of Afolayan et al. ${ }^{19}$ was in accordance with the present study, in which all the crude extracts possessed scavenging ability toward DPPH and ABTS radicals. Acetone crude extract highest scavenging potential in this study could be attributed with its phytochemicals composition..$^{13}$ This finding also indicated that acetone crude extract could be a promising natural antioxidant agent, in replacement of synthetic antioxidants characterized with undesirable side effects. ${ }^{2}$

Nitric oxide (NO) is a reactive nitrogen oxygen species with capability of alternating the structures functions of cellular components. Nitric acid also acts as pro-inflammatory mediators; it is produced by inducible nitric oxide synthase. ${ }^{27}$ In this study, all the crude extracts showed better NO scavenging activity than control (Ascorbic acid and BHA). This indicated that the crude extracts are potent NO scavenger which could serve as remedy in prevention of oxidative stress and inflammatory related diseases. ${ }^{27}$ Previously, medicinal plants have been reported to possessed NO scavenging ability. ${ }^{19}$ The crude extracts NO scavenging activity could also be linked to their phytochemicals composition. ${ }^{28}$ Hexane crude extract with lower $\mathrm{IC}_{50}$ values than other crude extracts and controls implied that they are the best scavengers of NO radicals.

\section{CONCLUSIONS}

Lippia Javanica's leaves were confirmed to consist of tannin, flavonoids, terpenoids, alkaloids and phenols, as phytochemical constituents. The percentage yield of crude extracts varies in increasing order; Acetone $>$ Methanol, $>$ Dichloromethane $>$ Ethyl-acetate $>$ Hexane. All the crude extract possessed antioxidant activity with differ degrees. Acetone crude extract showed highest scavenging ability toward DPPH and ABTS radical, whereas hexane crude showed more potent NO scavenging than others. This study proves that Lippia Javanica crude extract are good source of natural antioxidants in management of oxidative stress diseases. The isolation of bioactive compounds from crude extracts are desirable for future studies.

\section{ACKNOWLEDGEMENT}

The authors thanks South Africa National Research Funds (NRF) and Research Office of University of Zululand for funding this project.

\section{CONFLICT OF INTEREST}

There is no conflict of interest.

\section{ABBREVIATION}

ABTS: 2,21- Azino-bis (3-ethylbenzthiazoline-6- sulfonic acid; DPPH: 2,2-diphenyl-1-picrylhydrazyl; AA: Ascorbic acid BHA: Butylated hydroxy anisole; NO: Nitric oxide.

\section{REFERENCES}

1. Srikanth M, Devi B, Kotirataiah K, Ramanjaneyulu M, Sulthana PN, Suma RR. Phytochemical screening and in-vitro antioxidant activity of Peristrophe paniculata. Herbal Med: Open access. 2018;4(1):1-8.

2. Krishnaiah D, Sarbatly R, Nithyanandam R. A review of the antioxidant potential of medicinal plant species. Food Bioprod Process. 2011;8(9):217-33.

3. West JD, Marnett LJ. Endogenous reactive intermediates as modulators of cell signalling and cell death. Chem Res Toxicol. 2006;19:173-94.

4. James O, Unekwojo EG, Ojochenemi AA. Assessment of biological activities: A comparison of Pergularia daemia and Jatropha curcas leaf extracts. $\mathrm{Br}$ Biotechnol J. 2011;1:85-100.

5. Osunsanmi FO, Soyingbe OS, Ogunyinka IB, Mosa RA, Ikhile MI, Ngila JC, et al. Antiplatelet aggregation and cytotoxic activity of betulinic acid and its acetyl derivative from Melaleuca bracteata. J Med Plants Res. 2015;9(22):647-54

6. Swargiary A, Daimari A, Daimari M, Basumatary N, Narzary E. Phytochemicals, antioxidant, and anthelmintic activity of selected traditional wild edible plants of lower Assam. Indian J Pharmacol. 2016;48(4):418-23.

7. Al-Jaber NA, Awaad AS, Moses JE. Review on some antioxidant plants growing in Arab world. J Saudi Chem Soc. 2011;15:293-307. 
8. Chagonda LS, Chalchat JC. Essential oil compositionof Lippia javanica (Burm.f.) spreng chemotype from Western Zimbabwe. J Essent Oil Bear PI. 2015;18(2):482-5

9. Maroyi A. Lippia javanica (Burm.f.) Spreng traditional and commercial uses and phytochemical and pharmacological significance in the African and Indian subcontinent. Evid Based Complement Alternat Med. 2017; 2017(1):1-34

10. Shikanga EA, Combrinck S, Regnier T. South African Lippia herbal infusions: Total phenolic content, antioxidant and antibacterial activities. South African Journal of Botany. 2010;76 (3):567-71.

11. Sofowara AE. Medicinal plants and traditional medicine in Africa. 2nd ed. Ibadan, Nigeria: Spectrum Books Ltd.; 1993.p.289

12. Trease GE, Evans WC. Pharmacognsy. 11th ed. London: Brailliar Tiridel Can MacMillian Publishers; 1989.p.60-75.

13. Huda-Faujan N, Noriham A, Norrakiah AS, Babji AS. Antioxidant activity of plants methanolic extracts containing phenolic compounds. Afr J Biotechnol. 2009;8:484-9.

14. Otang WM, Grierson DS, Ndip RN. Phytochemical studies and antioxidant activity of two South African medicinal plants traditionally used for the management of opportunistic fungal infections in HIV/AIDS patients. BMC Comp Alter Med. 2012;12:43

15. Govindarajan R, Vijayakumar M, Pushpangadan P. Antioxidant approach to disease management and the role of 'Rasayana' herbs of Ayurveda. J Ethnopharmacol. 2005;99:165-78.

16. Ibrahim R, Abubakar EM, Modibbo S, Misauand L, Bala G. Percentage yield and acute toxicity of the plant extracts of Ceiba pentandra grown in Bauchi State, North Eastern Nigeria. J Pharmacogn Phytochem. 2017;6(5):1777-9.

17. Sandasi M, Kamatou GPP, Combrinck S, Viljoen AM. A chemotaxonomic assessment of four indigenous South African Lippia species using GC MS and vibrational spectroscopy of the essential oils. Biochem Syst Ecol. 2013;51(3):142-52.
18. Bhebhe M, FullerTN, Chipurura B, Muchuweti M. Effect of solvent type on total phenolic content and free radical scavenging activity of black tea and herbal infusions. Food Anal Method. 2016;9(4): 1060-7.

19. Afolayan AJ, Sharaibi OJ, Kazeem MI. Phytochemical analysis and in vitro antioxidant activity of Nymphaea lotus L. Int J Pharmacol. 2013;9(5):297-304.

20. Sultana A, Ashraf M. Effects of extraction solvent technique on the Antioxidant of selected medicinal plants extracts. Molecules. 2009;14:2167-80.

21. Gupta J. Comparison of different solvents for phytochemical extraction potential from Datura metel plant leaves. J Biol Chem. 2016;11(1):17-22.

22. Handral HK, Pandith A, Shruthi SD. A review on Murraya koenigii: Multipotential medicinal plant. Asian J Pharm Clin Res. 2012;5:5-14.

23. Arokiyaraj S, Martin S, Perinbam K, Arockianathan PM, Beatrice V. Free radical scavenging activity and HPTLC finger print of Pterocarpus santalinus L.- an in vitro study. Indian J Sci Technol. 2008;1:1-3.

24. Oki T, Masuda M., Furuta S, Nishiba Y, Terahara N, Suda I. Involvement of anthocyanins and other phenolic compounds in radical-scavenging activity of purple-fleshed sweet potato cultivars. J Food Sci. 2002;67:1752-6.

25. Walker RB, Everette JD. Comparative reaction rates of various antioxidants with ABTS radical cation. J Agric Food Chem. 2009;57:1156-61.

26. Wang M, Li J, Rangarajan M, Shao Y, LaVoie EJ, Huang TC, et al. Antioxidative phenolic compounds from sage (Salvia officinalis). J Agric Food Chem. 1998;46:4869-73.

27. Lu YC, Yeh WC, Ohashi PS. LPS/TLR4 signal transduction pathway. Cytokine. 2008;42:145-51.

28. Huang WY, Cai YZ, Zhang Y. Natural phenolic compounds from medicinal herbs and dietary plants: Potential use for cancer prevention. Nutr Cancer 2009;62:120.

\section{GRAPHICAL ABSTRACT}

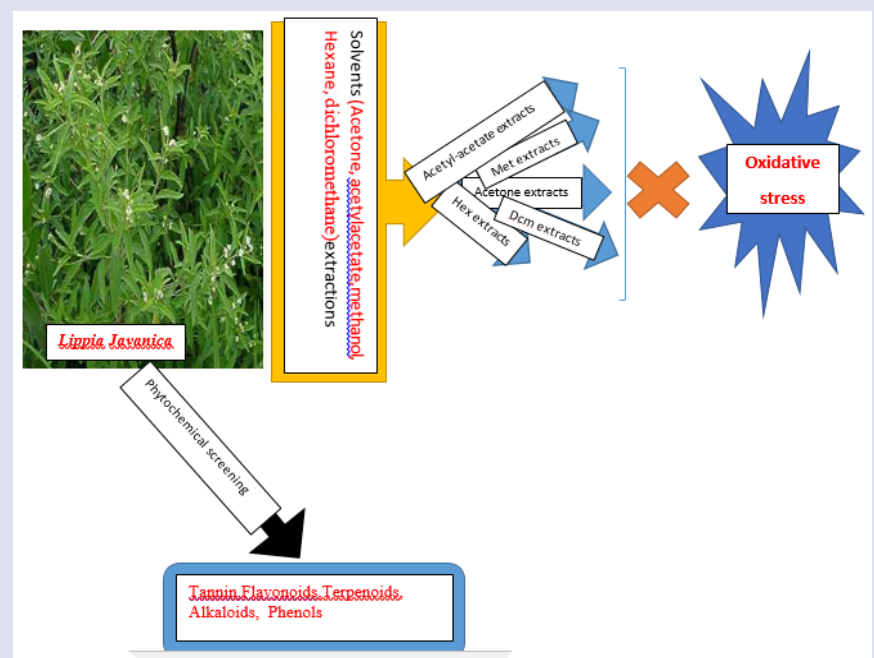

\section{SUMMARY}

- The phytochemical present in Lippia Javanica are tannin, flavonoids, terpenoids, alkaloids and phenols,

- Acetone crude extract showed the highest percentage yield in comparison with other solvents treatment.

- The crude extracts showed different degree of scavenging activity against ABTS, DPPH and NO radicals.

- Acetone crude extract showed the highest scavenging ability toward ABTS and DPPH radicals whereas, hexane crude extract showed the highest scavenging activity toward NO radicals.

- This study proves that extract from Lippia Javanica are good source of natural antioxidant in the management of oxidative stress diseases.

Cite this article: Osunsanmi FO, Zharare GE, Opoku AR. Phytochemical Constituents and Antioxidant Potential of Crude Extracts from Lippia Javanica (Burm.f.) Spreng Leaves. Pharmacog J. 2019;11(4):803-7. 